\title{
Distributional notes on some Nosodendridae (Coleoptera) - XX. Descriptions of a new species from the Philippines
}

\section{Замечания по распространению некоторых Nosodendridae (Coleoptera) - XX. Описание нового вида с Филиппин}

\author{
J. Háva \\ И. Гава
}

Daugavpils University, Institute of Life Sciences and Technology, Department of Biosystematics, Vienîbas Str. 13, Daugavpils LV5401 Latvia; Private Entomological Laboratory and Collection, Rýznerova 37, Únìtice u Prahy, Praha-západ CZ-252 62 Czech Republic. E-mail: jh.dermestidae@volny.cz.

Даугавпилсский университет, Институт естественных наук и технологий, отдел биосистематики, Даугавпилс LV-5401 Латвия; Частная энтомологическая лаборатория и коллекция, Прага, Чехия.

Key words: taxonomy, description, new species, Coleoptera, Nosodendridae, Nosodendron, Philippines.

Ключевые слова: таксономия, описание, новый вид, Coleoptera, Nosodendridae, Nosodendron, Филиппины.

\begin{abstract}
A new species, Nosodendron (Dendrodipnis) barsevskisi sp.n., from the Philippines is described, illustrated and compared with a close related species, Nosodendron (Dendrodipnis) nomurai Háva, 2000.

Резюме. В статье описывается новый вид Nosodendron (Dendrodipnis) barsevskisi sp.n. из Филиппин. Приводится сравнение нового вида с Nosodendron (Dendrodipnis) nomurai Háva, 2000.
\end{abstract}

\section{Introduction}

The small family Nosodendridae (Coleoptera) recently contains 2 genera and 101 species [Háva, 2019]. The classification of the family Nosodendridae is used according to Bouchard et al. [2011]. Seven species have been known from the Philippines [Háva, 2015, 2017, 2018] and a new species is described below.

\section{Material and Methods}

Locality labels of the mentioned material are cited in the original version. Specimens of the presently described species are provided with red, printed labels with the text as follows: «HOLOTYPE [or PARATYPE, respectively] Nosodendron (Dendrodipnis) barsevski$s i$ sp. n. Jiří Háva det. 2019».

Type material is deposited in collection: JHAC Jiří Háva, Private Entomological Laboratory and Collection, Prague-west, Czech Republic.

\section{Results}

Nosodendron (Dendrodipnis) barsevskisi Háva, sp.n.

Nosodendron nomurai: Háva [2017]: 6.

Type material. Philippines: Holotype: $\sigma^{7}-$ Palawan, 1.1991, (JHAC). Paratypes: 1 - - Mindanao, Bukidnon, Kabangalsan, Nov.2016, local collector, (JHAC);
1 - Mindanao, Lanao del Sur, Wao, Oct. 2016, local collector, (JHAC).

Description. Male. Measurements (in $\mathrm{mm}$ ): total length 5.3; maximum elytral width 3.5. Body convex. Cuticle black, shiny. Head finely, but clearly punctate, with very short yellow setae. Eyes large, visible from above. Antennae brown, with eleven antennomeres, antennal club with three antennomeres, with yellow setae. Mentum with small punctures, with short yellow setae, with U shaped groove. Pronotum punctate as head; with very short yellow setae. Pronotal anterior angle without groove. Scutellum triangular, finely punctate. Elytra with fine, short, yellow setae; each elytron with small punctures intermixed with small seta-bearing punctuation. Near scutellum each elytron with one short stria consisting of large punctures. Mesosternum finely and regularly punctate. Metasternum without longitudinal carina, punctures large on anterior margins, other punctures small. Legs black, tibiae and femora finely punctate, with short yellow setation. Abdominal visible ventrites black. Longitudinal striation of base of abdominal ventrites very long. Male genitalia figured.

Female. Externally similar to male. Measurements (in $\mathrm{mm}$ ): total length 5.3-5.5; maximum elytral width 3.0-3.1.

Differential diagnosis. The new species is very similar to Nosodendron nomurai Háva, 2000. Háva [2017] cited the species erroneously as $N$. nomurai. The species $N$. nomurai is excluded from the Philippine fauna. The new species differs by the characters mentioned in the following table (Talb. 1).

Etymology. Patronymic, dedicated to my friend and coleopterlogist Arvids Barševskis (Daugavpils, Latvia).

The Check-list of Nosodendridae recorded from Philippines is presented in Table 2 .

\section{Acknowledgements}

I am indebted very much to Jan Hrdlička (Czech Republic), for his help with the material from the Philippines and to Miloslav Rakovič (Czech Republic) for a revision of the English manuscript. 
Table 1. Differences between Nosodendron nomurai and N. barsevskisi sp.n.

Таблица 1. Отличия между Nosodendron nomurai и N. barsevskisi sp.n.

N. (D.) nomurai Háva, 2000

Mentum

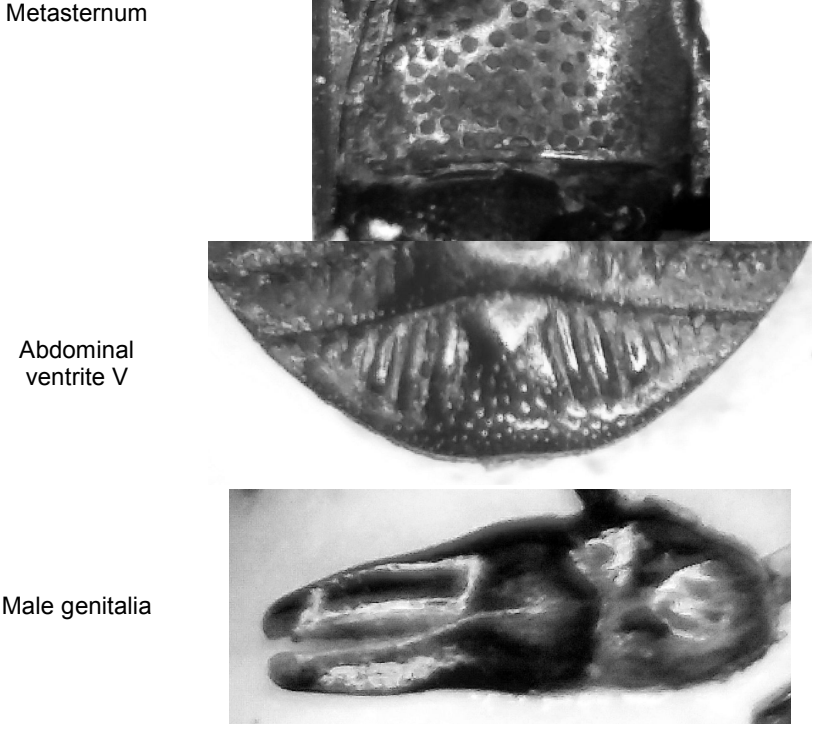

N. (D.) barsevskisi sp.n

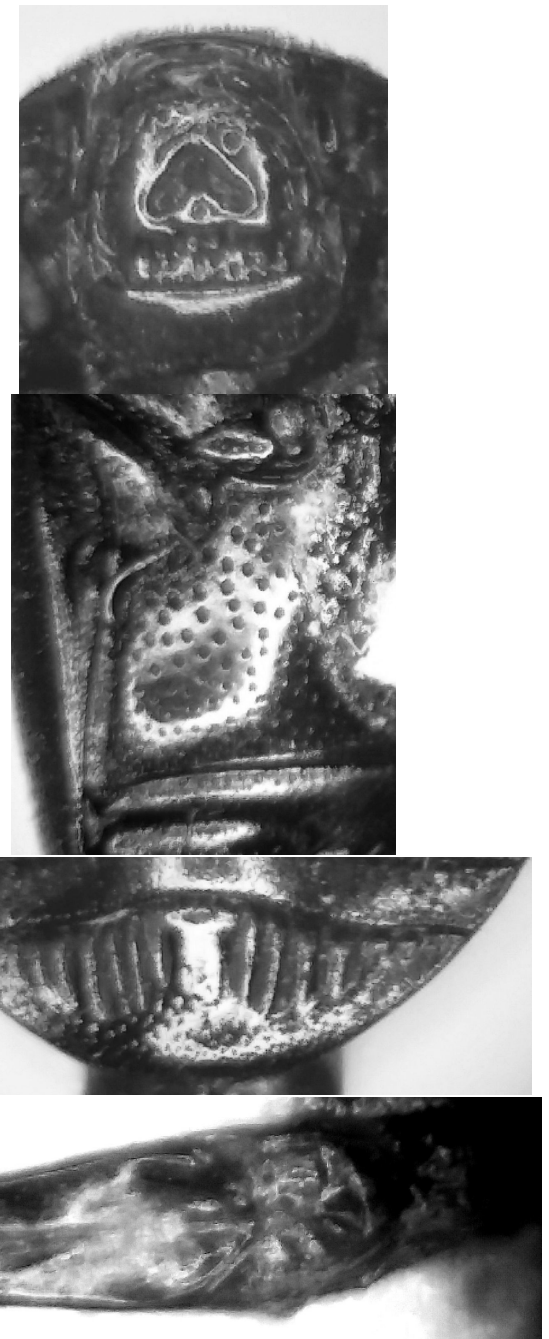

Table 2. Check-list of Nosodendridae recorded from Philippines Таблица 2. Список видов Nosodendridae , отмеченных с Филипин

\begin{tabular}{|l|l|}
\hline \multicolumn{1}{|c|}{ Species } & \multicolumn{1}{c|}{ Distribution } \\
\hline \multicolumn{1}{|c|}{$\begin{array}{r}\text { Nosodendridae Erichson, 1846 } \\
\text { Nosodendron }\end{array}$} \\
\multicolumn{1}{|c|}{$\begin{array}{c}\text { Latreille, 1804 } \\
\text { Nosodendron (Dendrodipnis) Wollaston, 1873 }\end{array}$} \\
\hline Nosodendron barsevskisi sp.n. & Palawan; Mindanao \\
\hline Nosodendron bolmi Háva, 2015 & Mindanao \\
\hline Nosodendron hispidum Champion, 1923 & Palawan \\
\hline Nosodendron lentum Oehme-Leonhardt, 1954 & Mindanao \\
\hline Nosodendron luzonicus Háva, 2018 & Luzon \\
\hline Nosodendron mindanaoensis Háva, 2018 & Mindanao \\
\hline Nosodendron parahispidum Háva, 2015 & Mindanao \\
\hline Nosodendron planus Háva, 2015 & Mindanao \\
\hline
\end{tabular}




\section{References}

Bouchard P., Bousquet Y., Davies A.E., Alonso-Zarazaga M.A., Lawrence J.F., Lyal Ch.H.C., Newton A.F., Reid Ch.A.M., Schmitt M., Slipinski S.A., Smith A.B.T. 2011. Familygroup names in Coleoptera (Insecta) // ZooKeys. Vol.88. P.1-972.

Háva J. 2015. Distributional notes on some Nosodendridae (Coleoptera) - XIV. Descriptions of three new species and new faunistics records from Philippines // Entomologische Zeitschrift. Bd.125. P.223-224.
Háva J. 2017. Distributional notes on some Nosodendridae (Coleoptera) - XVI. New faunistics records from the Philippines // Acta Biologicae Universitates Daugavpiliensis. Vol.17. No.1. P.5-7.

Háva J. 2018. Distributional notes on some Nosodendridae (Coleoptera) - XVIII. Descriptions of two new species from the Philippines // Folia Heyrovskyana. Ser.A. Vol.26. No.2. P. 1-3.

Háva J. 2019. Nosodendridae deposited in the Canadian Museum of Nature, with new records and descriptions of three new species // Baltic Journal of Coleopterology. Vol.19. No.1. P.77-87.

Поступила в редакцию 25.10.2019 